\title{
Effect of different habitat types on abundance and biting times of Anopheles balabacensis Baisas (Diptera: Culicidae) in Kudat district of Sabah, Malaysia
}

\author{
Tock H. Chua ${ }^{1 *}$, Benny O. Manin ${ }^{1}$, Indra Vythilingam² ${ }^{2}$, Kimberly Fornace ${ }^{3}$ and Chris J. Drakeley ${ }^{3}$
}

\begin{abstract}
Background: We investigated the effect of five common habitat types on the diversity and abundance of Anopheles spp. and on the biting rate and time of Anopheles balabacensis (currently the only known vector for Plasmodium knowlesi in Sabah) at Paradason village, Kudat, Sabah. The habitats were forest edge, playground area, longhouse, oil palm plantation and shrub-bushes area. Sampling of Anopheles was done monthly using the human landing catch method in all habitat types for 14 months (October 2013 to December 2014, excluding June 2014). The Anopheles species were morphologically identified and subjected to PCR assay for the detection of Plasmodium parasites. Generalised linear mixed models (GLMM) were applied to test the variation in abundance and biting rates of An. balabacensis in different habitat types.
\end{abstract}

Results: A total of 1599 Anopheles specimens were collected in the village, of which about 90\% were An. balabacensis. Anopheles balabacensis was present throughout the year and was the dominant Anopheles species in all habitat types. The shrub bushes habitat had the highest Anopheles species diversity while forest edge had the greatest number of Anopheles individuals caught. GLMM analysis indicated that An. balabacensis abundance was not affected by the type of habitats, and it was more active during the early and late night compared to predawn and dawn. PCR assay showed that $1.61 \%$ of the tested An. balabacensis were positive for malaria parasites, most of which were caught in oil palm estates and infected with one to two Plasmodium species.

Conclusions: The identification of infected vectors in a range of habitats, including agricultural and farming areas, illustrates the potential for humans to be exposed to P. knowlesi outside forested areas. This finding contributes to a growing body of evidence implicating environmental changes due to deforestation, expansion of agricultural and farming areas, and development of human settlements near to forest fringes in the emergence of $P$. knowlesi in Sabah.

Keywords: Anopheles balabacensis, Abundance, Habitat type, Biting time, Malaria vector, Plasmodium knowlesi, Sabah, Malaysia

\footnotetext{
*Correspondence: thchua@ums.edu.my

${ }^{1}$ Department of Pathobiology and Medical Diagnostics, Faculty of Medicine and Health Sciences, Universiti Malaysia Sabah, Kota Kinabalu, Sabah, Malaysia

Full list of author information is available at the end of the article
} 


\section{Background}

Borneo Island, the third largest island in the world, is famous for its diverse and unique flora and fauna. Unfortunately, Borneo Island has been experiencing forest losses recently. From 1975 to 2015, approximately 18.5 million hectares (Mha) of old forests were cleared for industrial plantations [1]. In 2015, an estimated 7.9 Mha of the total Borneo landmass (73.7 Mha) were planted with oil palm. Changes in the environment due to deforestation, mainly for development, logging and agricultural plantations, are also changing the ecology of animals on the island, including anopheline ecology [2]. With continued deforestation across Borneo [3], resulting fragmentation of forest areas may increase the spillover risk of zoonotic, vector-borne diseases due to increased contact between humans and disease reservoirs and vectors [4].

Sabah, the second largest state in Malaysia, situated in northern Borneo Island with an estimated area of $73,620 \mathrm{~km}^{2}$ has recently experienced tremendous forest loss. Prior to the 1980 s, about $80 \%$ of Sabah was covered with mainly dipterocarp forests [5]. However, by the mid-1980s, only $60 \%$ of Sabah was covered with forest, a loss of $20 \%$ in a short time due to logging and agriculture activities. By 1995, about $90 \%$ of the primary forests in Sabah had been lost, with the area reduced from around 2.8 to $0.3 \mathrm{Mha}$ [5].

One of the current major mosquito borne-diseases in Sabah is zoonotic knowlesi malaria caused by Plasmodium knowlesi transmitted from long-tailed and pig-tailed macaques by Anopheles mosquitoes [6]. In 2016, 93\% of the knowlesi malaria cases in Malaysia (1263/1357) were reported from Malaysian Borneo [7]. Deforestation and land alteration have been thought as the main reasons behind the increase of knowlesi malaria cases by creating new habitat types suitable for the Anopheles vector [8].

In Southeast Asia, Anopheles species are present in high diversity, including species complexes that occur in sympatry but have different behavior $[9,10]$. The high diversity of these vectors and the complexity of the species could lead to misidentification which may influence the success of vector control programmes $[11,12]$. In East Malaysia, An. balabacensis and An. latens have been confirmed as the main vectors for $P$. knowlesi in Sabah and Sarawak, respectively [13, 14]. In Peninsular Malaysia, several species of Anopheles belonging to the Leucosphyrus group had been identified as the natural vectors for P. knowlesi [15]. Nevertheless, other Anopheles sp. (e.g. An. kochi) can act as vectors for P. knowlesi but further studies are needed to establish their role in transmission [16].
In Asia, P. knowlesi was probably the first simian malaria confirmed to cause widespread human infection after a group of villagers had been found infected naturally in Kapit, Sarawak, East Malaysia in 2004 [17]. This species was previously misidentified as $P$. falciparum or $P$. malariae [18] until molecular techniques were introduced. Since then, $P$. knowlesi cases have also been reported in Sabah [19-21] and Peninsular Malaysia [2224]. Similarly, many other countries in Southeast Asia have also reported cases, e.g. Kalimantan, Indonesia [25, 26]; Sumatra, Indonesia [27]; Brunei [28]; Thailand [29, 30]; Vietnam [31, 32]; Singapore [16, 33]; Phillippines [34]; Myanmar [35]; Cambodia [36]; and recently Laos [37].

In this study, we conducted an entomological investigation to determine the diversity and abundance of Anopheles species, especially An. balabacensis, in the five types of habitats that are now commonly found in the rural areas of Sabah. Anopheles balabacensis has been known as the dominant species in Kudat Division, mainly in Banggi Island located off the northern coast of Sabah near Marudu Bay [38]. Current changes in the landscape of Kudat district of Kudat Division have provided new habitats for An. balabacensis closer to human settlements, have altered its distribution, increased their opportunity of feeding on humans and infecting them with malaria parasites.

\section{Methods}

\section{Sampling site}

Kudat Division of Sabah is the smallest division, and covers the districts of Kudat, Pitas, Kota Marudu, Balambangan, Banggi Island and several other islands. The climate in Sabah is tropical with an average temperature of $32{ }^{\circ} \mathrm{C}$ for lowland areas and $21{ }^{\circ} \mathrm{C}$ for highland areas, typically hot and sunny the whole year. Rainfall is common throughout the year and influenced by northeast (November to March) and southwest monsoons (May to September).

This study was carried out in Kudat district (Fig. 1) which receives a high volume of rain during the northeast monsoon but less rain during the southwest monsoon. The population of Kudat district was about 85,300 in July 2010 with the majority of Rungus ethnicity [39]. They live in several hamlets each consisting of several houses or longhouses. The villagers practice swidden farming, growing rice, corn and vegetables for their own consumption. Some families might have their own small plantation of coconut, rubber or oil palm but many work as laborers in oil palm plantations.

Sampling of Anopheles mosquitoes was conducted in Paradason village [40] $\left(6^{\circ} 46^{\prime} 11.75^{\prime \prime} \mathrm{N}, 116^{\circ} 47^{\prime} 3.23^{\prime \prime} \mathrm{E}\right)$ which had 28 households and 122 residents in October 


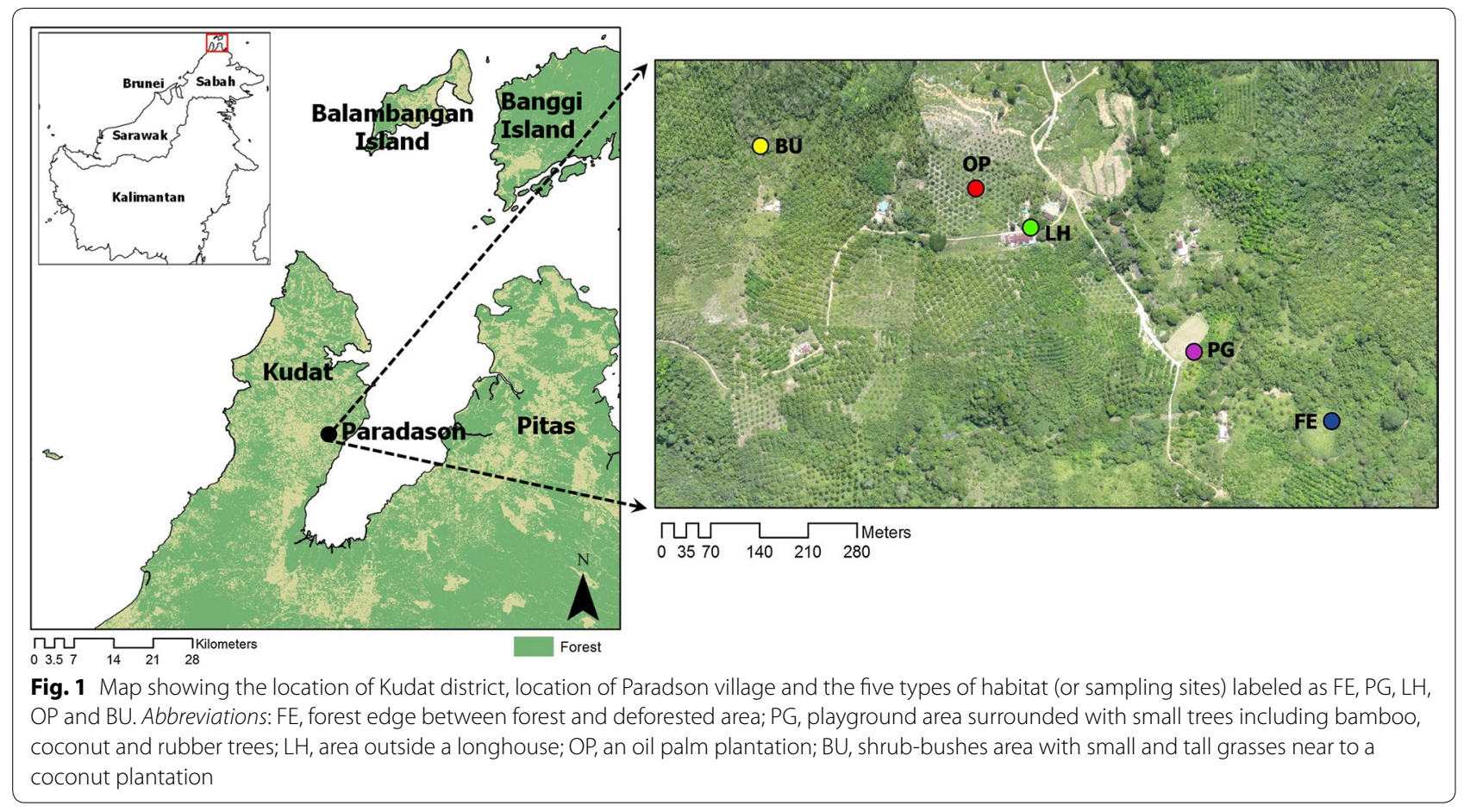

2013 census (Fig. 1). Prior to and within the study period five knowlesi malaria cases had been reported from this village. Long-tailed macaques were also sighted in the surrounding areas. The village has an area of about $1.98 \mathrm{~km}^{2}$ comprising forest, plantation, farm and human settlement areas. Five types of habitats were selected: a forest edge between secondary forest and deforested area (FE); a playground area (or an open space area) surrounded with small trees including bamboo, coconut and rubber trees where the village youths gather during evening to play football (PG); an area outside a longhouse ( $\mathrm{LH})$; a farm which was converted into an oil palm plantation (OP); and a shrub-bushes area with small and tall grasses near to a coconut plantation (BU) (Fig. 2).

Anopheles mosquitoes were collected by the human landing catch (HLC) method, with two persons in a team, which involved exposing lower part of their legs to attract mosquitoes. Mosquitoes that landed on their legs were captured using a plastic specimen tube $(2 \mathrm{~cm}$ diameter $\times 6 \mathrm{~cm}$ length). Each captured mosquito was placed in a separate specimen tube which was labeled with the time of capture. The mosquitoes were sampled from 18:00-06:00 h (12 h). Sampling was done once a month for 14 months starting in October 2013 and ending in December 2014 with no sampling in June 2014. Meteorological data such as temperature, humidity and rainfall were obtained from Kudat meteorological station which was located $17 \mathrm{~km}$ from Paradason village.

\section{Morphological identification of Anopheles mosquitoes}

The Anopheles mosquitoes were killed by keeping them in a freezer $\left(-20^{\circ} \mathrm{C}\right)$ and each individual was identified based on morphological characteristics using published keys [41-44]. Anopheles specimens were mounted onto $\mathrm{Nu}$ poly strip using ultra-thin micro-headless pin and identified under a compound microscope. Each individual mosquito was kept separately in a clean microfuge tube and transported to the Faculty of Medicine \& Health Sciences, Universiti Malaysia, Sabah, for further processing.

\section{Species composition, diversity and evenness}

The diversity index of Anopheles mosquitoes in each habitat type was determined using the Shannon-Wiener index, $H$ [45]. This index is commonly used to characterize species diversity in a community which accounts for both abundance and evenness of the species present. Evenness assumes a value between 0 and 1 with 1 being complete evenness. The index is calculated based on the formula, $H=-\sum_{i=1}^{S} P_{i}\left(\ln P_{i}\right)$ where $S$ is the number of species and $P_{\mathrm{i}}$ is the proportion of individuals of $\mathrm{i}_{t h}$ species.

\section{Extraction of total DNA from Anopheles mosquitoes}

Each Anopheles individual was placed separately in a clean mortar and the tissue was homogenized using a sterile pestle. The total DNA was extracted from each individual using the DTAB-CTAB method [46] with 

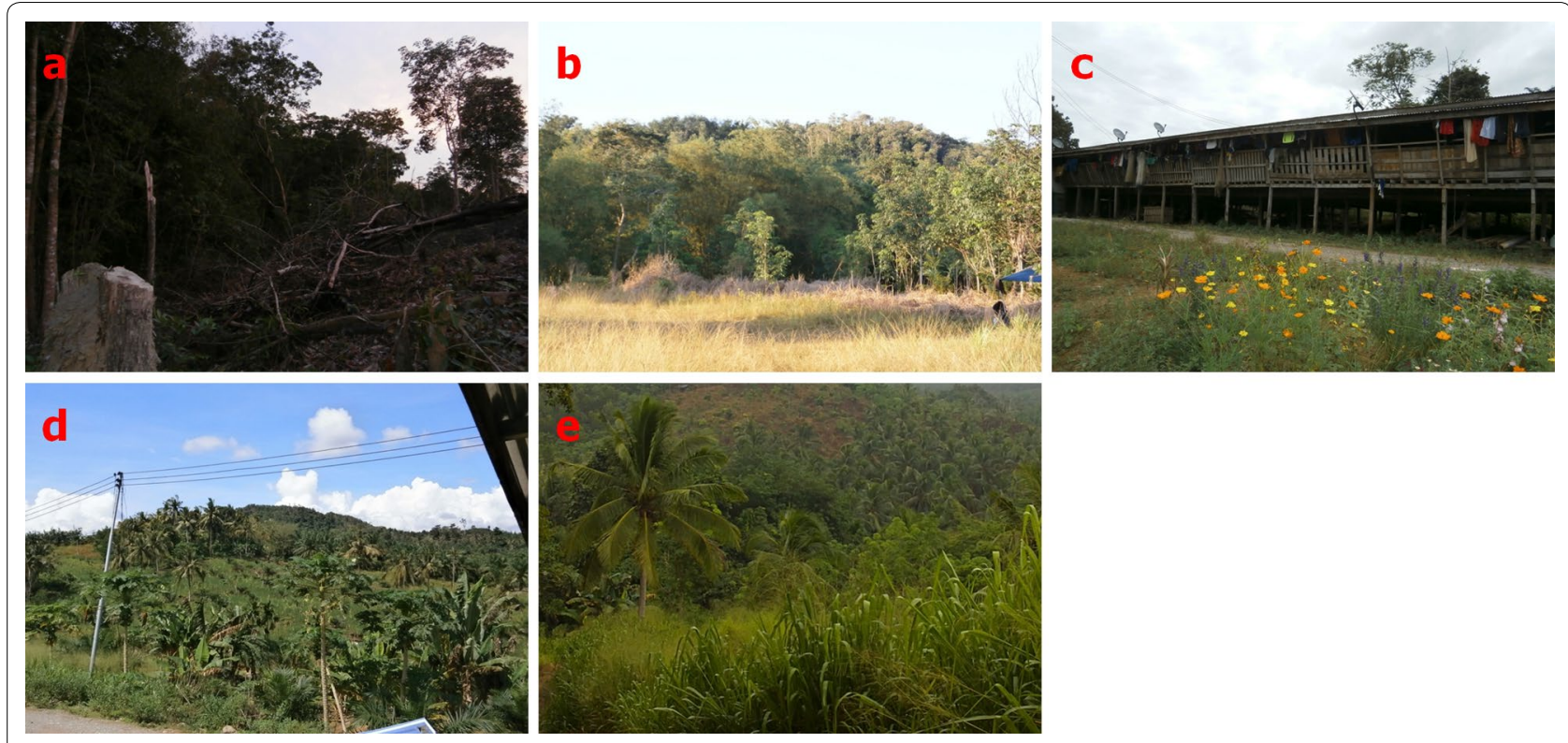

Fig. 2 The habitat types where mosquitoes were sampled are: a FE, forest edge between forest and deforested area; $\mathbf{b}$ PG, playground area surrounded with small trees including bamboo, coconut and rubber trees; $\mathbf{c} L H$, area outside a longhouse; $\mathbf{d}$ OP, an oil palm plantation; and e BU, shrub-bushes area with small and tall grasses near to a coconut plantation

some modifications. First, $600 \mu \mathrm{l}$ of DTAB solution was added into the mortar and the tissue was ground using pestle until homogenized. Then, the homogenized tissue was transferred into a clean $1.5 \mathrm{ml}$ microcentrifuge tube and incubated at $68{ }^{\circ} \mathrm{C}$ for $30 \mathrm{~min}$. Subsequently, $700 \mu \mathrm{l}$ of chloroform was added into the microcentrifuge tube which was inverted ten times to mix the contents and centrifuged at $13,000 \times \mathrm{rpm}$ for $5 \mathrm{~min}$. Then, $400 \mu \mathrm{l}$ of the upper aqueous layer was carefully transferred into a new clean $1.5 \mathrm{ml}$ microcentrifuge tube and mixed with $900 \mu \mathrm{l}$ of sterile $\mathrm{dH}_{2} \mathrm{O}$ and $100 \mu \mathrm{l} \mathrm{CTAB}$ solution by gently inverting the microcentrifuge tube several times. The tube was then allowed it to sit at room temperature for 5 min and spun at $13,000 \times \mathrm{rpm}$ for $10 \mathrm{~min}$. The supernatant was discarded and the DNA pellet was re-suspended in $300 \mu \mathrm{l}$ of $1.2 \mathrm{M} \mathrm{NaCl}$ solution. Total DNA was precipitated by adding $750 \mu \mathrm{l}$ of absolute ethanol and centrifuged at $13,000 \times \mathrm{rpm}$ for $5 \mathrm{~min}$. Then, the supernatant was discarded and the DNA was washed with $500 \mu \mathrm{l}$ of $70 \%$ ethanol and centrifuged at 13,000 $\times \mathrm{rpm}$ for $2 \mathrm{~min}$. The DNA pellet was air-dried at $45^{\circ} \mathrm{C}$ for $10 \mathrm{~min}$, re-suspended in $30 \mu \mathrm{l}$ of Tris-EDTA (pH8.0) buffer and stored at $-30{ }^{\circ} \mathrm{C}$ until use.

\section{Detection of malaria parasites}

The presence of malaria parasites in the mosquitoes was detected using nested PCR assay by targeting the small subunit ribosomal RNA (SSU rRNA) gene of Plasmodium. The PCR primer pair rPLU1 and rPLU5 were used in first PCR reaction, while rPLU3 and rPLU4 were used in the second reaction [47]. For internal control, another nested PCR reaction was performed separately at the same time to amplify the cytochrome $c$ oxidase subunit 2 ( $\cos 2)$ gene of Anopheles [48]. When a specimen was found positive for malaria parasites, further identification of Plasmodium sp. was conducted using nine speciesspecific primers (Additional file 1: Table S1). For positive control, known positive DNA of each Plasmodium species was obtained from the Parasitology and Medical Entomology Laboratory, Faculty of Medicine and Health Sciences, Universiti Malaysia Sabah and tested with the nine species-specific PCR primers (Additional file 2: Figure S1).

Both PCR genus-specific and species-specific reactions were performed in a final volume of $25.0 \mu$ l. Reaction components were prepared by mixing $5.0 \mu \mathrm{l}$ of $5 \times \mathrm{PCR}$ buffer (Promega, Madison, WI, USA), $0.5 \mu \mathrm{l}$ of $(10 \mathrm{mM})$ dNTPs (Promega), $3.0 \mu \mathrm{l}$ of $(25 \mathrm{mM}) \mathrm{MgCl}_{2}, 1.0 \mu \mathrm{l}$ of $(10$ $\mu \mathrm{M})$ forward and reverse primers, $0.3 \mu \mathrm{l}$ of $(5.0 \mathrm{U} / \mu \mathrm{l}) \mathrm{Taq}$ DNA polymerase (Promega), $2.0 \mu \mathrm{l}$ of DNA template and sterile $\mathrm{dH}_{2} \mathrm{O}$ up to $25.0 \mu \mathrm{l}$ final volume. After completion of the first PCR, $2.0 \mu \mathrm{l}$ of the PCR products was used as a DNA template in the second PCR. The reaction was carried out using a thermal cycler $\left(\mathrm{T} 100^{\mathrm{TM}}\right.$ Thermal Cycler, Bio-Rad, California, CA, USA) with the following conditions: initial denaturation at $95{ }^{\circ} \mathrm{C}$ for $5 \mathrm{~min} ; 35$ cycles of denaturation at $94{ }^{\circ} \mathrm{C}$ for $1 \mathrm{~min}$, annealing for $1 \mathrm{~min}$ and extension at $72{ }^{\circ} \mathrm{C}$ for $1 \mathrm{~min}$; final extension at $72{ }^{\circ} \mathrm{C}$ 
for $5 \mathrm{~min}$. The annealing temperature used was based on the optimal temperature for each set of primers (Additional file 1: Table S1). PCR products were analyzed on $1.5 \%$ agarose gel electrophoresis stained with RedSafe ${ }^{\mathrm{TM}}$ nucleic acid staining solution (iNtRON Biotechnology, Jungwon-Seongnam, South Korea) and visualized using UV transilluminator.

\section{Analysis of relationship between An. balabacensis and meteorological data}

The correlation between the number of An. balabacensis caught per person per night with temperature, relative humidity and rainfall from Kudat meteorological station was examined using Pearson's linear correlation coefficient $(r)$ and checked for significance. The test was conducted using SPSS v.18 for Windows 10.

\section{Analysis of abundance of An. balabacensis}

Statistical analysis of mosquito abundance was conducted using $\mathrm{R}$ programming software for statistical analysis (v.3.2.2). Generalised linear mixed models (GLMM) were constructed to test the variation in abundance of $A n$. balabacensis related to month of collection, types of habitat and time of biting. This model included both fixed and random predictor variables in the analysis. Time of biting was categorized into four periods for the total catch of An. balabacensis: 18:00-21:00 h (early night); 21:0000:00 h (late night); 0:00-03:00 h (predawn); and 03:0006:00 $\mathrm{h}$ (dawn). In the analysis, the type of habitat and the time of biting were considered as fixed effects. Month was fitted alternatively as fixed (to predict monthly value) and random effect (to test differences between types of habitat and time of biting while controlling variation in seasonality). In order to determine the best model, both negative binomial and Poisson distributions including zero inflation were tested in the model. Tukey's post-hoc test was used to compare predicted means between the fixed effects and the interaction between the two fixed effects.

\section{Results}

Anopheles species composition, diversity and evenness

A total of ten Anopheles species were recorded from Paradason village (Table 1). The highest number of species was recorded from shrub bushes (BU, 10 species) and the least was from oil palm plantation (OP, 4 species). Anopheles balabacensis was the dominant species in all types of habitat with the total number caught reaching 90\% (1437/1599). The highest number of Anopheles was recorded from the forest edge (FE, 21.58\%) followed by oil palm (OP, 20.39\%) and shrub bushes (BU, 20.39\%), longhouse (LH, 19.07\%) and playground (PG, 18.57\%). Overall, the diversity of Anopheles mosquito in Paradason village is considered low as indicated by the evenness value of 0.2 .

\section{Abundance of An. balabacensis by month and habitat type A total of 1437 individuals of $A n$. balabacensis were caught for the 70 sampling nights pooling all the habitats at Paradason village, equivalent to $10.3 \pm 0.47$ bites per man per night. The fluctuations in the monthly number of An. balabacensis caught in the five types of habitat showed similar trends (Fig. 3). The GLMM predicted the highest mean monthly number of $A n$. balabacensis for}

Table 1 Total numbers of Anopheles species caught from each type of habitat from October 2013 to December 2014

\begin{tabular}{|c|c|c|c|c|c|c|}
\hline Species & $\mathrm{FE}$ & PG & $\mathrm{LH}$ & $\mathrm{OP}$ & $\mathrm{BU}$ & Total \\
\hline An. balabacensis & 316 & 264 & 274 & 299 & 284 & 1437 \\
\hline An. barbumbrosus & 13 & 14 & 20 & 21 & 24 & 92 \\
\hline An.donaldi & 9 & 4 & 2 & 0 & 4 & 19 \\
\hline An. maculatus & 2 & 10 & 5 & 0 & 5 & 22 \\
\hline An. nigerrimus & 3 & 0 & 1 & 0 & 1 & 5 \\
\hline An. peditaeniatus & 0 & 3 & 0 & 0 & 1 & 4 \\
\hline An. separatus & 0 & 0 & 0 & 0 & 1 & 1 \\
\hline An. sundaicus & 0 & 0 & 1 & 0 & 1 & 2 \\
\hline An.tessellatus & 2 & 2 & 2 & 4 & 4 & 14 \\
\hline An. umbrosus & 0 & 0 & 0 & 2 & 1 & 3 \\
\hline Total no. of specimens & 345 & 297 & 305 & 326 & 326 & 1599 \\
\hline Total no. of species & 6 & 6 & 7 & 4 & 10 & 10 \\
\hline Shannon-Wiener index, $H$ & 0.40 & 0.50 & 0.45 & 0.34 & 0.57 & 0.47 \\
\hline$H_{\max }$ & 1.79 & 1.79 & 1.95 & 1.39 & 2.30 & 2.30 \\
\hline Evenness & 0.22 & 0.28 & 0.23 & 0.25 & 0.25 & 0.20 \\
\hline
\end{tabular}

Abbreviations: $\mathrm{FE}$, forest edge; $\mathrm{PG}$, playground; LH, longhouse; OP, oil palm plantation; $\mathrm{BU}$, shrub bushes 


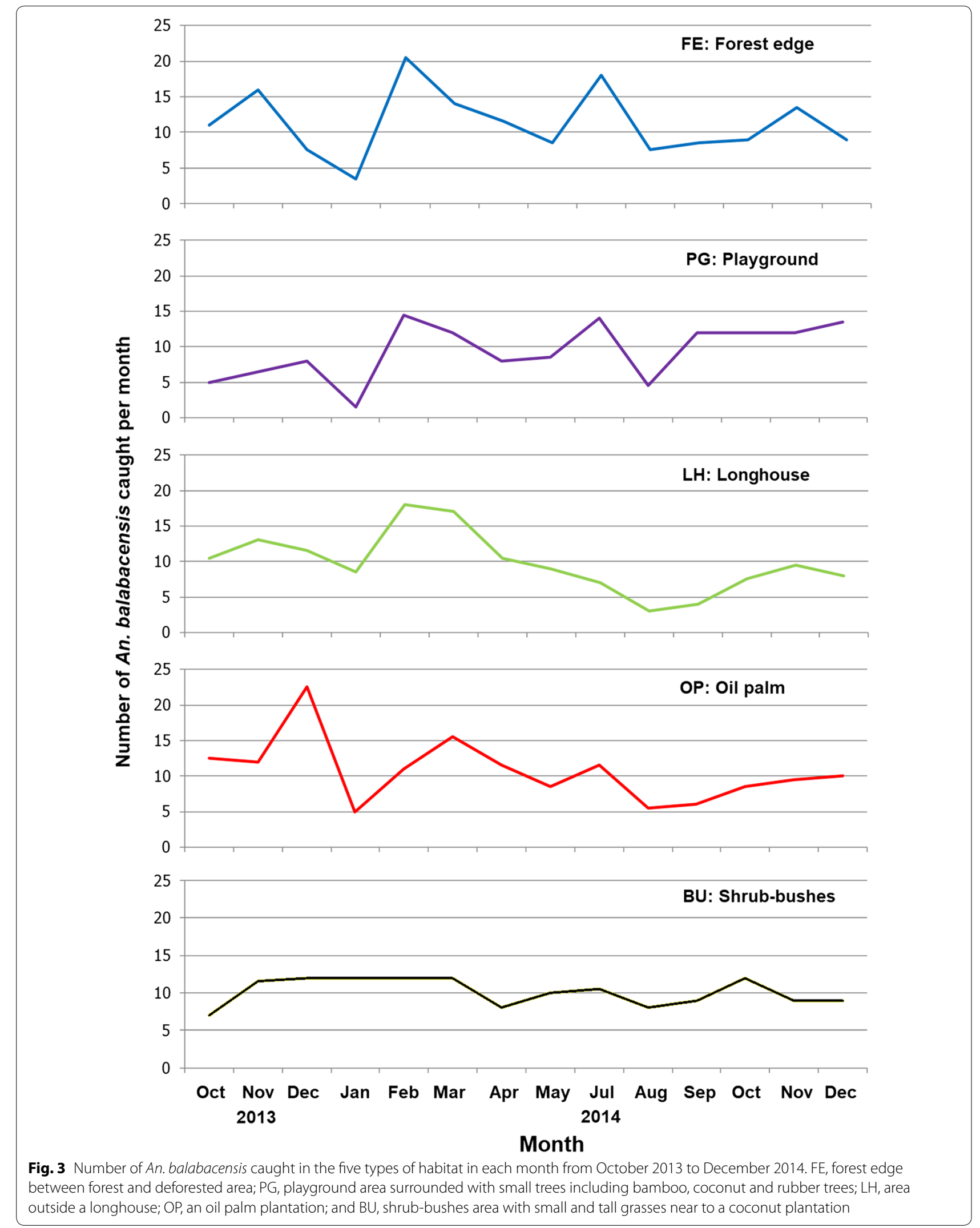


February (15.0 \pm 3.06 bites per man per night) and the lowest for August ( $5.40 \pm 1.52$ bites per man per night). Fitting the model with a Poisson distribution and comparing the predicted mean between all months showed that there was a significant difference only between December 2013 and August 2014 (12.0 \pm 1.55 bites per man per night versus $5.40 \pm 1.52$ bites per man per night, $Z=3.44, P=0.0372$ ) and between February 2014 and August 2014 (15.0 \pm 3.06 bites per man per night versus $5.40 \pm 1.52$ bites per man per night, $Z=-3.59$, $P=0.0231$ ).

The mean bites per man per night for each habitat type predicted by GLMM were $10.7 \pm 1.67,10.1 \pm 1.58$, $9.8 \pm 1.03,9.3 \pm 1.50$ and $9.0 \pm 1.50$ for forest edge, oil palm estates, bushes, longhouse and playground, respectively. However, using a Poisson distribution in the model, no difference was detected in the number caught between the different habitat types.

During the study period, the range of the mean monthly temperature, relative humidity and rainfall in Kudat district were $25.9-28.4{ }^{\circ} \mathrm{C}, 80.4-87.5 \% \mathrm{RH}$ and 0-27.8 mm, respectively (Fig. 4). Analysis of the number of An. balabacensis caught on each sampling night against the environmental factors of the day showed significant correlation between the numbers of An. balabacensis caught with temperature $(r=-0.243, P=0.043)$, but not with relative humidity $(r=0.220, P=0.067)$ and rainfall $(r=0.204, P=0.090)$ (Fig. 5).

\section{Biting time of An. balabacensis}

Overall, biting times of An. balabacensis from different types of habitat was similar with a peak biting time of 19:00-20:00 $\mathrm{h}$ in PG, LH, OP and BU and 20:00-21:00 $\mathrm{h}$ in FE (Fig. 6). More An. balabacensis were caught within the first three hours after dusk (18:00-21:00 h) with the number decreasing gradually until dawn. Only one mosquito bite per person or less in each hour after midnight was recorded. Fitting the model with a Poisson distribution, there were significant differences between the catch at early night versus predawn, early night versus dawn, late night versus predawn, late night versus dawn, and predawn versus dawn (Table 2).

Analysis of interaction between habitat type and time-period showed that only three interactions were significant, namely $\mathrm{FE} \times$ early night versus $\mathrm{FE} \times$ dawn, $\mathrm{BU} \times$ early night versus $\mathrm{BU} \times$ dawn, and $\mathrm{BU} \times$ late night versus $\mathrm{BU} \times$ dawn (Additional file 3: Table S2).

\section{Presence of malaria parasites in Anopheles specimens}

A total of 1586 Anopheles specimens were tested for malaria parasites using a PCR assay, and only 23 (1.45\%) were found positive. These were all An. balabacensis, constituting $1.6 \%$ or $23 / 1425$ of the species collected. Most infected specimens were caught in the oil palm plantation and shrub bushes, and during early and late night. These An. balabacensis were infected with one or two simian malaria species with $P$. inui being the most common species, while P. knowlesi was found in two mosquitoes only (Table 3; representative figures of agarose gels are shown in Additional file 4: Figure S2).

\section{Discussion}

We conducted a survey at Paradason village, in Kudat district, Sabah to investigate if the diversity and abundance of adult Anopheles is influenced by the habitat types that are generally found in the rural areas of Sabah, namely forest edge, playground, longhouse, oil palm plantation and shrub bushes.

We collected ten Anopheles species from all the habitats, among which An. balabacensis was the dominant species in all types of habitat. The dominance of this species in Kudat Division was also noted previously [14],

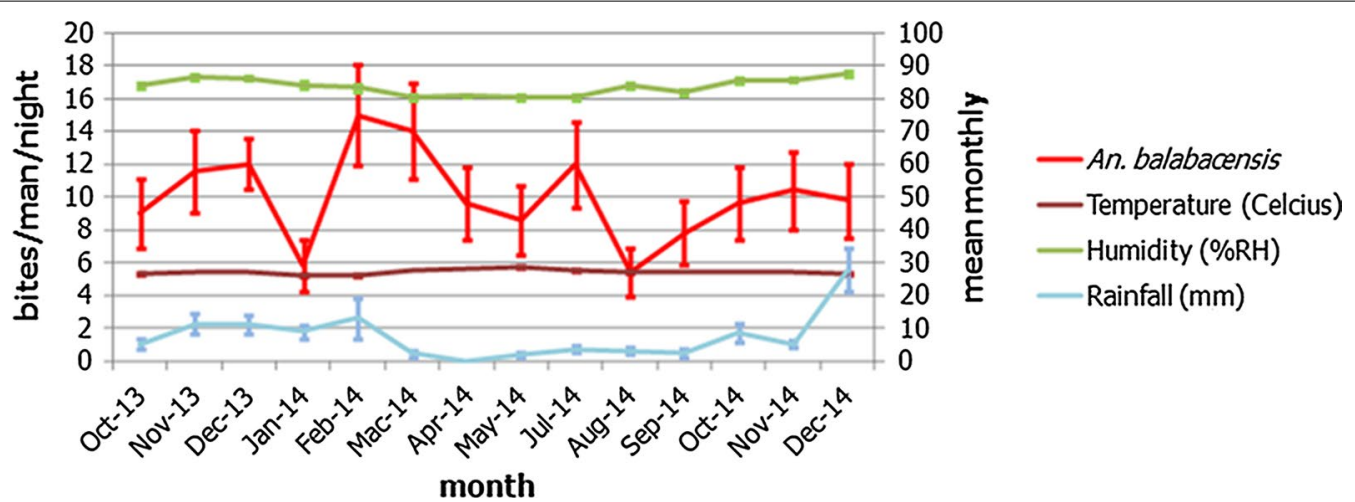

Fig. 4 Monthly mean temperature, relative humidity and rainfall and the number of An. balabacensis collected in Kudat district from October 2013 to December 2014 

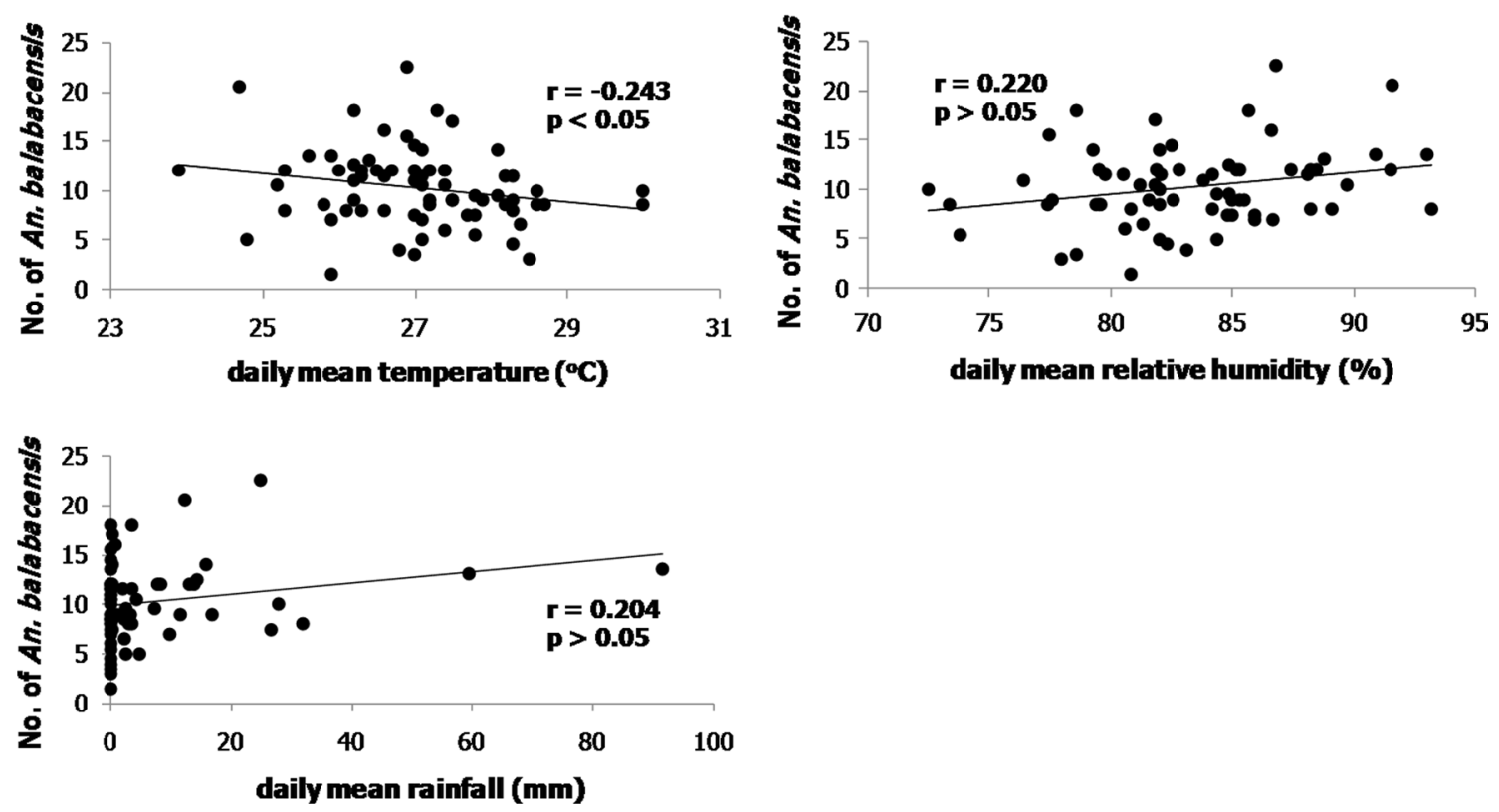

Fig. 5 Plot of An. balabacensis (bites/man/night) caught on each sampling night ( $n=70$ ) against the environmental factors: mean daily temperature; mean daily relative humidity; and mean daily rainfall

although our study in Tajau Laut village located further north of Kudat indicated that An. balabacensis and An. tessellatus were almost equally common [48]. However, differences in the dominant Anopheles species have been reported in different locations across the wider state of Sabah, possibly due to heterogeneities in the surrounding environments. For example, in the northern area of Ranau district, An. maculatus was recorded as the dominant species, followed by An. balabacensis and An. donaldi [49], while in Kinabatangan district $A n$. donaldi was the dominant species replacing An. balabacensis, possibly due to the development and malaria control activities conducted there [50]. Our recent data from Paus village in southern part of Ranau district showed that the dominant species is An. donaldi followed by $A n$. balabacensis and An. barbumbrosus (unpublished data). Further south in Keningau district, in Keritan Ulu village, An. maculatus, An. balabacensis and An. barbumbrosus were almost equally abundant (Additional file 5: Table S3). Overall, the diversity of Anopheles species in Paradason village is considered low as indicated by the evenness index due to overwhelming abundance of $A n$. balabacensis in all types of habitat.

Anopheles balabacensis has been known as the dominant and common Anopheles species in Kudat Division of Sabah since 1980s [38] and as an efficient human malaria vector in Sabah since 1950s [51, 52]. Now, almost 40 years later, this species still ranks high among the dominant Anopheles species in Kudat district despite significant land use and land cover changes, due to development for human settlements, infrastructure, farming and plantations $[8,53]$. Our findings suggest that $A n$. balabacensis is adaptable and able to thrive in the manmade environment, with relatively high densities in plantation and farm areas. This is evident by the presence of An. balabacensis breeding sites observed in oil palm plantation near to human settlements. Similar inference was drawn for An. cracens in Peninsular Malaysia [54] and An. dirus (s.l.) in Thailand [55], both of which have adapted and colonized the forest edge and plantations after deforestation.

The shrub-bush habitat recorded the highest number of Anopheles species. This could be a result of shrub and bushes providing ample refuge areas for resting before and after blood meals [56], and shade for the breeding sites in both permanent and temporary water bodies. In the Paradason area, this bush habitat was observed in close proximity to human settlements, farms, plantations and deforested areas, which could be a source of infective Anopheles. Furthermore, a troop of long-tailed macaques was also observed in study site especially in the morning (06:00-07:00 h) and evening (16:00-18:00 h) coming from a nearby forest area into a coconut farm to forage for food. These monkeys were positive for P. knowlesi [57], just as those in other parts of Malaysia which recorded 50-97\% positive [58-60].

Although forest activities have previously been associated with increased human risk of $P$. knowlesi within this 


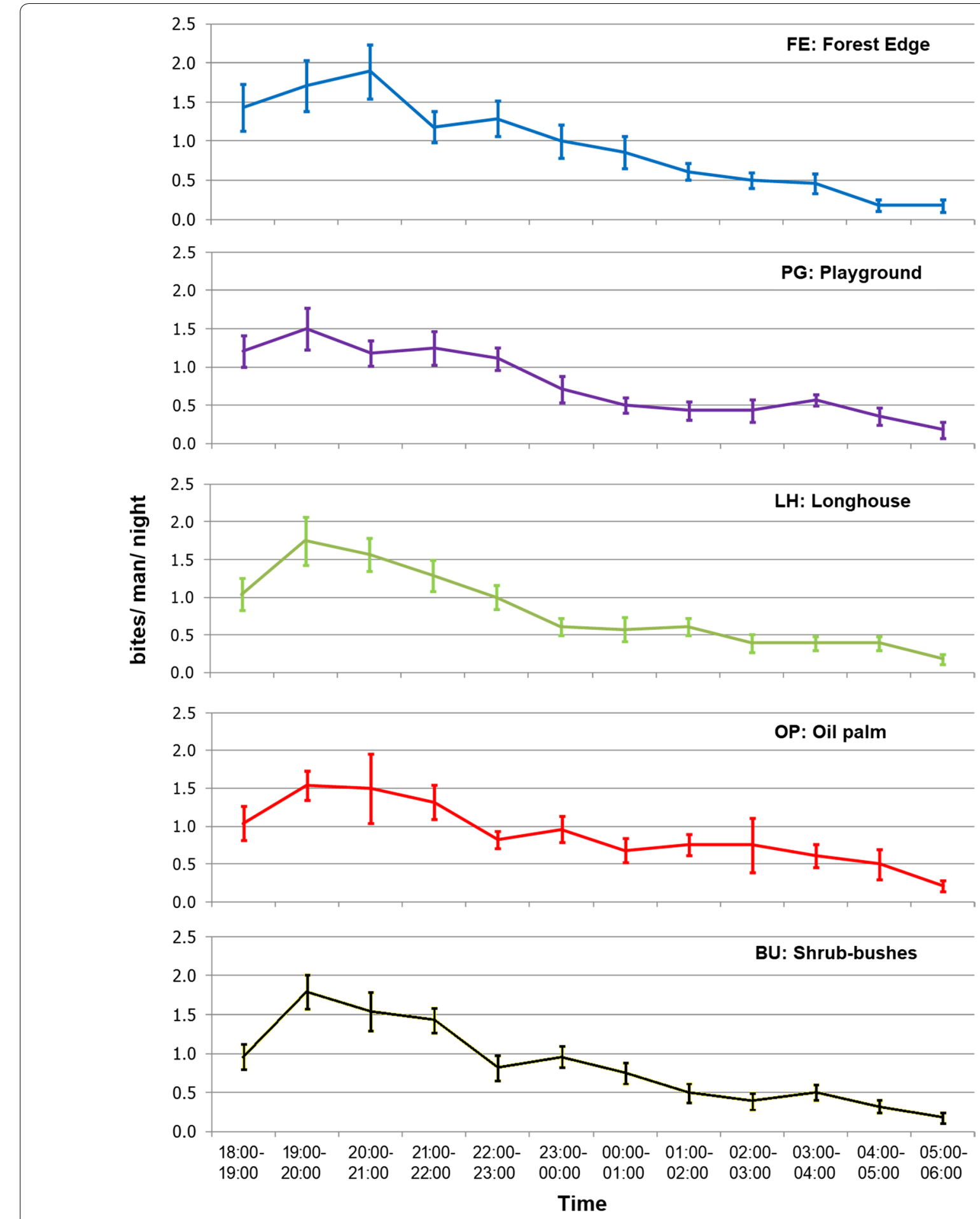

Fig. 6 Mean number of bites/man/night (and 95\% standard error bars) of An. balabacensis recorded in each hour for the various types of habitat

area [61], GLMM analysis indicated that there was no difference in number of An. balabacensis caught at various habitat types, indicating individuals have a risk of being exposed to an infected mosquito across habitat types.
Although the HLC was conducted on different nights at each habitat type which may introduce bias between sampling, An. balabacensis is known to have a short flight distance with an average maximum flight distance 
Table 2 Mean biting rate for each time period of catch as predicted by GLMM

\begin{tabular}{|c|c|c|c|}
\hline Time period & Time & Mean $\pm S E$ (bites/man/time period) & Significant differences $^{a}$ \\
\hline Early night & $18: 00-21: 00 h$ & $3.9 \pm 0.72$ & $\begin{array}{l}\text { Early night vs Late night: } P=0.2472 \text {; } \\
\text { Early night vs Predawn: } P<0.0001 \text {; }\end{array}$ \\
\hline Late night & 21:00-00:00 h & $2.8 \pm 0.53$ & $\begin{array}{l}\text { Early night vs Dawn: } P<0.0001 \\
\text { Late night vs Predawn: } P=0.0024\end{array}$ \\
\hline Predawn & 00:00-03:00 h & $1.4 \pm 0.29$ & $\begin{array}{l}\text { Late night vs Dawn: } P<0.0001 \\
\text { Predawn vs Dawn: } P=0.0011\end{array}$ \\
\hline Dawn & 03:00-06:00 h & $0.7 \pm 0.11$ & \\
\hline
\end{tabular}

a Detected by Tukey's test between the pairs of time periods

Table 3 Number of Plasmodium-infected An. balabacensis caught from each habitat type, the recorded biting time and the Plasmodium species as detected using PCR assay

\begin{tabular}{|c|c|c|c|}
\hline Habitat & No. of infected An. balabacensis & Biting time & Plasmodium spp. \\
\hline \multirow[t]{3}{*}{ Forest edge (FE) $(n=315)$} & \multirow[t]{3}{*}{4} & Early night & P. knowlesi + P. cynomolgi \\
\hline & & Late night $(n=2)$ & P. inui, P. cynomolgi \\
\hline & & Predawn & P. inui \\
\hline Playground (PG) $(n=260)$ & 1 & Early night & P. inui \\
\hline \multirow[t]{3}{*}{ Longhouse $(\mathrm{LH})(n=270)$} & \multirow[t]{3}{*}{4} & Late night & P. inui \\
\hline & & Predawn $(n=2)$ & P. inui, P. cynomolgi \\
\hline & & Dawn & P. coatneyi \\
\hline \multirow[t]{3}{*}{ Oil palm plantation (OP) $(n=299)$} & \multirow[t]{3}{*}{7} & Early night $(n=4)$ & P. inui $(n=3)$, P. coatneyi \\
\hline & & Late night $(n=2)$ & P. inui, P. fieldi + P. cynomolgi \\
\hline & & Dawn & P.inui \\
\hline \multirow[t]{4}{*}{ Shrub bushes (BU) $(n=281)$} & \multirow[t]{4}{*}{7} & Early night $(n=2)$ & P. inui, P. inui + P. cynomolgi \\
\hline & & Late night $(n=2)$ & P. coatneyi, P. knowlesi $+P$. inui \\
\hline & & Predawn $(n=2)$ & P. cynomolgi $(n=2)$ \\
\hline & & Dawn & P. inui + P. cynomolgi \\
\hline
\end{tabular}

Abbreviation: $\mathrm{n}$, number of specimens

of less than 500 meters [62]. This suggests An. balabacensis is likely to stay in close proximity to breeding sites, as observed with An. farauti (s.l.) [10] and conducting HLCs on different nights between habitat types is not likely to substantially impact results of this study.

Data on the biting times indicate that An. balabacensis starts to be actively biting as soon as it gets dark, especially at the forest edge or bush areas that have been deforested, highlighting the need for vector control measures targeting these times when people are unlikely to be sleeping under a bednet. A previous study [63] also showed more An. balabacensis bite humans in logged forest as compared to primary and virgin reserve forests. This study did not identify a significant difference in abundance of An. balabacensis between early and late nights; however, human exposure may be higher earlier in the night when people are more likely to visit these environments. A previous study in Kudat demonstrated the risk of getting bitten by An. balabacensis was higher for those who stay outside the house after dusk
(18:00-00:00 h) as compared to those who stay inside [64]. The number of Anopheles mosquitoes seeking blood meals at night might be dependent on natural preferences, host availability and environmental conditions such as temperature, relative humidity, rainfall, moonlight and wind speed [65-67]. Anopheles balabacensis in this study area showed a significant negative correlation with temperature but did not show a significant correlation with the increment of relative humidity and rainfall. The lack of correlation between the mosquito catch and rainfall could be due to the localized variations in rainfall and microclimate as data was only available from the Kudat meteorological station, located 17 kilometers from the sampling site at Paradason village.

Only $1.45 \%$ of all Anopheles specimens were found infected with simian Plasmodium and of these only An. balabacensis was positive. However, since whole mosquitoes were processed, infectious (oocyst positive) and infective (salivary glands positive) individuals cannot be differentiated. Most of the infections were by single 
species, P. inui (47.8\%), followed by P. cynomolgi (17.4\%). In addition, the two mosquitoes infected with $P$. knowles $i$ were also co-infected either with $P$. inui or $P$. cynomolgi. These two specimens were caught at the forest edge and shrub bushes habitats, respectively, where a troop of long-tailed macaques had been observed.

Anopheles balabacensis is a vector for P. knowlesi as well as for other simian malaria parasites $[14,64]$. Furthermore, we could not detect any human malaria parasites by PCR in the Anopheles specimens although $P$. falciparum and $P$. vivax cases have been reported in Kudat district $[19,68]$. This contrasts with findings in Vietnam in which An. dirus (s.l.), a primary vector for P. knowlesi, had co-infections with $P$. vivax and $P$. falciparum $[31,69]$. The majority of the positive An. balabacensis was infected with $P$. inui, another species of simian malaria parasite that has a high possibility of becoming zoonotic. Although there has not yet been a report of naturally acquired $P$. inui in humans, experimentally it has been shown that humans are susceptible to this species and will develop fever if infected [70]. Another simian Plasmodium that is of great concern is $P$. cynomolgi as this has been reported infecting humans under natural conditions [71, 72]. Furthermore, the real number of $P$. cynomolgi infection in humans might be underestimated as this species could be misidentified as $P$. vivax by microscopy [71].

Although there was no difference in vector densities, molecular results indicated that a higher proportion (65.2\%) of infected An. balabacensis was caught earlier in the evening between 18:00 $\mathrm{h}$ and midnight. Although these numbers are limited, this suggests people may be at a higher risk of getting infected with malaria during this period, especially when they are still outside their houses.

\section{Conclusions}

The dominant Anopheles species in Kudat district is $A n$. balabacensis which could be found equally abundant in different types of habitats, suggesting people are at a risk of exposure to infected vectors across a range of environments. Further work is needed to characterise the breeding sites within these different habitats. While limited numbers of infected An. balabacensis were caught, the presence of infected vectors in oil palm estates demonstrates the need for vector control measures targeting these habitats. Furthermore, mixed infections with $P$. knowlesi and other zoonotic malaria species illustrates the potential for spillover into human populations and the need for further surveillance. While deforestation and agricultural expansion can create economic opportunities, these changes may also increase spatial overlap between human, macaque and vector populations in new habitat types, presenting a challenge for malaria elimination.

\section{Additional files}

Additional file 1: Table S1. PCR primers used for detecting Plasmodium spp. in Anopheles specimens.

Additional file 2: Figure S1. Amplification of known Plasmodium DNA using Plasmodium genus and species-specific PCR primers. Lanes M: 1.0 kb DNA ladder (Promega); Lane a: genus Plasmodium, 240 bp (rPLU3 + rPLU4); Lane b: P. coatneyi, 504 bp (PctF1 + PctR1); Lane c: P. inui, 479 bp (PinF2 + INAR3); Lane d: P. fieldi, 421 bp (PfldF1 + PfldR2); Lane e: $P$. cynomolgi, 137 bp (CY2F + CY4R); Lane f: P. knowlesi, 424 bp (PkF1140+ PkR1550); Lane g: P. falciparum, 370 bp (NewPLFshort + FARshort); Lane h: P. vivax, 476 bp (NewPLFshort + VIRshort); Lane i: P. malariae, 241 bp (NewPLFshort + MARshort); Lane j: P. ovale, 407 bp (NewPLFshort + OVRshort); Lane k: negative control (no DNA template).

Additional file 3: Table S2. Mean interaction statistic between habitat type and time period as predicted by GLMM. Habitat types: FE: forest edge; PG: playground; LH: longhouse; OP: oil palm plantation; BU: shrub bushes. Time periods are: early night (18:00-21:00 h); late night (21:00-00:00 h); predawn (00:00-03:00 h); dawn (03:00-06:00 h).

Additional file 4: Figure S2. Detection and identification of Plasmodium in Anopheles. Top: Anopheles specimens PD171-PD183 using Plasmodium genus-specific PCR primers. Internal control targeting cox2 gene of Anopheles was used. The numbers represent replicate 1 and 2 . Lanes $M$ : 1.0 kb DNA ladder; J: infected Anopheles with Plasmodium; K: non-infected Anopheles; L: negative control (no DNA template). Bottom: Anopheles specimen PD178 using nine species-specific PCR primers. Lanes M: 1.0 kb DNA ladder; a: genus Plasmodium; b: P. coatneyi; c: P. inui; d: P. fieldi; e: P. cynomolgi; f: P. knowlesi; g: P. falciparum; h: P. vivax; i: P. malariae; j: P. ovale; k: negative control.

Additional file 5: Table S3. Total Anopheles specimens collected at study sites in Paus, Ranau and Keritan Ulu, Keningau.

\section{Abbreviations}

PCR: polymerase chain reaction; GLMM: generalised linear mixed model; MHa: million hectares; HLC: human landing catch; DNA: deoxyribonucleic acid; DTAB: dodecyltrimethylammonium bromide; CTAB: cetyltrimethylammonium bromide; SSU rRNA: small subunit ribosomal RNA; cox2: cytochrome c oxidase subunit II.

\section{Acknowledgments}

The authors would like to acknowledge the Universiti Malaysia Sabah for all the research facilities provided, Mr Fazreen and Mr Nemran for helping in the fieldwork. We would also like to acknowledge the community of Paradason for their cooperation and warm hospitality during this study.

\section{Authors' contributions}

THC, IV, KF and CJD designed the conceptualization of the study. CJD acquired the funding. THC, BOM, IV and CJD designed the experiments. BOM and THC implemented the experiments and collected the data. BOM identified the specimens and carried out molecular analysis. THC and BOM carried out statistical analysis. BOM and THC drafted the manuscript. All authors contributed to drafting the manuscript. All authors read and approved the final manuscript.

\section{Funding}

This study was funded by the Medical Research Council, Natural Environment Research Council, Economic and Social Research Council, and Biotechnology and Biosciences Research Council through the Environmental and Social Ecology of Human Infectious Diseases Initiative, grant no. G1100796.

\section{Availability of data and materials}

The datasets supporting the conclusions of this article are included within the article and its additional files. 


\section{Ethics approval and consent to participate}

This study was approved by the National Medical Research Register of the Malaysian Ministry of Health (NMRR, Reference No. NMRR-12-786-13048). Consent to carry out mosquito collection was obtained from the village council or the village headman and the land owners. All volunteers who carried out mosquito collections signed informed consent forms and were provided with antimalarial prophylaxis during the study period.

\section{Consent for publication}

Not applicable.

\section{Competing interests}

The authors declare that they have no competing interests.

\section{Author details}

${ }^{1}$ Department of Pathobiology and Medical Diagnostics, Faculty of Medicine and Health Sciences, Universiti Malaysia Sabah, Kota Kinabalu, Sabah, Malaysia. ${ }^{2}$ Department of Parasitology, Faculty of Medicine, University of Malaya, Kuala Lumpur, Malaysia. ${ }^{3}$ Faculty of Infectious and Tropical Diseases, London School of Hygiene and Tropical Medicine, London, UK.

\section{Received: 18 March 2019 Accepted: 19 July 2019}

Published online: 25 July 2019

\section{References}

1. Gaveau DLA, Sheil D, Husnayaen A, Salim MA, Arjasakusuma S, Ancrenaz $\mathrm{M}$, et al. Rapid conversions and avoided deforestation: examining four decades of industrial plantation expansion in Borneo. Sci Rep. 2016:6:32017

2. Yasuoka J, Levins R. Impact of deforestation and agricultural development on anopheline ecology and malaria epidemiology. Am J Trop Med Hyg. 2007;76:450-60.

3. Gaveau DLA, Sloan S, Molidena E, Yaen H, Sheil D, Abram NK, et al. Four decades of forest persistence, clearance and logging on Borneo. PLoS ONE. 2014;9:e101654.

4. Imai N, White MT, Ghani AC, Drakeley CJ. Transmission and control of Plasmodium knowlesi: a mathematical modelling study. PLoS Negl Trop Dis. 2014:8:e2978.

5. Gunggut H, Saufi K, Zaaba Z, Liu MSM. Where have all the forests gone Deforestation in land below the wind. Procedia Soc Behav Sci. 2014; 153:363-9

6. Millar SB, Cox-Singh J. Human infections with Plasmodium knowlesizoonotic malaria. Clin Microbiol Infect. 2015;21:640-8.

7. World Health Organization Malaria Policy Advisory Committee. Outcomes from the evidence review group on Plasmodium knowlesi. 2017. http:// www.who.int/malaria/mpac/mpac-mar2017-plasmodium-knowlesipresentation. Accessed 7 Apr 2018

8. Fornace KM, Abidin TR, Alexander N, Brock P, Grigg MJ, Murphy A, et al. Association between landscape factors and spatial patterns of Plasmodium knowlesi infections in Sabah, Malaysia. Emerg Infect Dis. 2016;22:201-8.

9. Morgan K, Somboon P, Walton C. Understanding Anopheles diversity in Southeast Asia. Rijeka: InTech; 2013. p. 327-55.

10. Sinka ME, Bangs MJ, Manguin S, Chareonviriyaphap T, Patil AP, Temperley WH, et al. The dominant Anopheles vectors of human malaria in the AsiaPacific region: occurrence data, distribution maps and bionomic précis. Parasit Vectors. 2011:4:89.

11. Bortel WV, Harbach RE, Trung HD, Roelants P, Backeljau T, Coosemans M. Confirmation of Anopheles varuna in Vietnam, previously misidentified and mistargeted as the malaria vector Anopheles minimus. Am J Trop Med Hyg. 2001;65:729-32.

12. Saeung A. Anopheles (Diptera: Culicidae) species complex in Thailand: identification, distribution, bionomics and malaria-vector importance. Int J Parasitol Res. 2012;4:75-82

13. Vythilingam I, Tan CH, Asmad M, Chan ST, Lee KS, Singh B. Natural transmission of Plasmodium knowlesi to humans by Anopheles latens in Sarawak, Malaysia. Trans R Soc Trop Med Hyg. 2006;100:1087-8.

14. Wong ML, Chua TH, Leong CS, Khaw LT, Fornace K, Wan-Sulaiman WY, et al. Seasonal and spatial dynamics of the primary vector of Plasmodium knowlesi within a major transmission focus in Sabah, Malaysia. PLoS Negl Trop Dis. 2015;9:e0004135.

15. Vythilingam I, Wong ML, Wan-Yussof WS. Current status of Plasmodium knowlesi vectors: a public health concern? Parasitology. 2018;145:32-40.

16. Jeslyn WPS, Huat TC, Vernon L, Irene LMZ, Sung LK, Jarrod LP, et al. Molecular epidemiological investigation of Plasmodium knowlesi in humans and macaques in Singapore. Vector Borne Zoonotic Dis. 2011;11:131-5.

17. Singh B, Sung LK, Matusop A, Radhakrishnan A, Shamsul SSG, Cox-Singh $J$, et al. A large focus of naturally acquired Plasmodium knowlesi infections in human beings. Lancet. 2004;363:1017-24.

18. Lee KS, Cox-Singh J, Singh B. Morphological features and differential counts of Plasmodium knowlesi parasites in naturally acquired human infections. Malar J. 2009;8:73.

19. Barber BE, William T, Dhararah P, Anderios F, Grigg M, Yeo TW, et al. Epidemiology of Plasmodium knowlesi malaria in north-east Sabah, Malaysia: family clusters and wide age distributions. Malar J. 2012;11:401.

20. Barber BE, William T, Grigg MJ, Menon J, Auburn S, Marfurt J, et al. A prospective comparative study of knowlesi, falciparum, and vivax malaria in Sabah, Malaysia: high proportion with severe disease from Plasmodium knowlesi and Plasmodium vivax but no mortality with early referral and artesunate therapy. Clin Infect Dis. 2013;56:383-97.

21. Goh XT, Lim YA, Vythilingam I, Chew CH, Lee PC, Ngui R, et al. Increased detection of Plasmodium knowlesi in Sandakan division, Sabah as revealed by PlasmoNex ${ }^{\text {TM }}$. Malar J. 2013;12:264.

22. Jiram Al, Hisam S, Reuben $H$, Husin SZ, Roslan A, Ismail WRW. Submicroscopic evidence of the simian malaria parasite, Plasmodium knowlesi, in an orang asli community. SE Asian J Trop Med Public Health. 2016;47:591-9.

23. Lee WC, Chin PW, Lau YL, Chin LC, Fong MY, Yap CJ, et al. Hyperparasitaemic human Plasmodium knowlesi infection with atypical morphology in peninsular Malaysia. Malar J. 2013;12:88.

24. Yusof R, Lau YL, Mahmud R, Fong MY, Jelip J, Ngian HU, et al. High proportion of knowlesi malaria in recent malaria cases in Malaysia. Malar J. 2014;13:168.

25. Figtree M, Lee R, Bain L, Kennedy T, Mackertich S, Urban M, et al. Plasmodium knowlesi in human, Indonesian Borneo. Emerging. Infect Dis. 2010;16:672-4

26. Setiadi W, Sudoyo $H$, Trimarsanto $H$, Sihite BA, Saragih RJ, Juliawaty $R$, et al, A zoonotic human infection with simian malaria, Plasmodium knowlesi, in central Kalimantan. Indonesia. Malar J. 2016:15:218.

27. Lubis IND, Wijaya H, Lubis M, Lubis CP, Divis PCS, Beshir KB, et al. Contribution of Plasmodium knowlesi to multispecies human malaria infections in North Sumatera, Indonesia. J Infect Dis. 2017;215:1148-55.

28. Ramaswami A, Pisharam JK, Aung H, Ghazala K, Maboud K, Chong VH, et al. Co-incidental Plasmodium knowlesi and mucormycosis infections presenting with acute kidney injury and lower gastrointestinal bleeding. Am J Case Rep. 2013:14:103-5.

29. Jongwutiwes S, Putaporntip C, Iwasaki T, Sata T, Kanbara H. Naturally acquired Plasmodium knowlesi malaria in human, Thailand. Emerg Infect Dis. 2004;10:2211-3.

30. Jongwutiwes S, Buppan P, Kosuvin R, Seethamchai S, Pattanawong U, Sirichaisinthop J, et al. Plasmodium knowlesi malaria in humans and macaques, Thailand. Emerg Infect Dis. 2011;17:1799-806.

31. Marchand RP, Culleton R, Maeno Y, Quang NT, Nakazawa S. Co-infections of Plasmodium knowlesi, P. falciparum, and P. vivax among humans and Anopheles dirus mosquitoes, Southern Vietnam. Emerg Infect Dis. 2011;17:1232-8.

32. Van den Eede P, Van HN, Overmeir CV, Vythilingam I, Duc TN, Hung LX, et al. Human Plasmodium knowlesi infections in young children in central Vietnam. Malar J. 2009:8:249.

33. Ng OT, Ooi EE, Lee CC, Lee PJ, Ng LC, Wong PS, et al. Naturally acquired human Plasmodium knowlesi infection, Singapore. Emerg Infect Dis. 2008;14:814-6.

34. Luchavez J, Espino F, Curameng P, Espina R, Bell D, Chiodini P, et al. Human infections with Plasmodium knowlesi, the Philippines. Emerg Infect Dis. 2008;14:811-3.

35. Jiang N, Chang Q, Sun X, Lu H, Yin J, Zhang Z, et al. Co-infections with Plasmodium knowlesi and other malaria parasites, Myanmar. Emerg Infect Dis. 2010:16:1476-8. 
36. Khim N, Siv S, Kim S, Mueller T, Fleischmann E, Singh B, et al. Plasmodium knowlesi infection in humans, Cambodia, 2007-2010. Emerg Infect Dis. 2011;17:1900-2.

37. Iwagami M, Nakatsu M, Khattignavong P, Soundala P, Lorphachan L, Keomalaphet $\mathrm{S}$, et al. First case of human infection with Plasmodium knowlesi in Laos. PLoS Negl Trop Dis. 2018;12:e0006244.

38. Hii JLK, Kan S, Vun YS, Chin KF, Tambakau S, Chan MKC, et al. Transmission dynamics and estimates of malaria vectorial capacity for Anopheles balabacensis and An. flavirostris (Diptera: Culicidae) on Banggi island, Sabah, Malaysia. Ann Trop Med Parasitol. 1988;82:91-101.

39. Sabah State Department of Health. 2016 Annual Report of Unit for Control of Vector Borne Diseases (RKPBV), Division of Public Health, Sabah, Malaysia; 2016 (Jabatan Kesihatan Negeri Sabah. Laporan Tahunan RKPBV 2016. Unit Rancangan Kawalan Penyakit Bawaan Vektor, Bahagian Kesihatan Awam, JKNS; 2016).

40. Fornace KM, Herman LS, Abidin TR, Chua TH, Daim S, Lorenzo PJ, et al. Exposure and infection to Plasmodium knowlesi in case study communities in northern Sabah, Malaysia and Palawan, The Philippines. PLoS Negl Trop Dis. 2018;12:e0006432.

41. Cagampang-Ramos A, Darsie Jr RF. Illustrated keys to the Anopheles mosquitoes of the Philippine Islands. Malaria Eradication Training Center, Technical Report 70-1, USAF Fifth Epidemiological Flight. Manila: PACAF; 1970.

42. Rattanarithikul R, Harrison B, Harbach RE, Panthusiri P, Coleman RE. Illustrated keys to the mosquitoes of Thailand IV. Anopheles. Southeast Asian J Trop Med Public Health. 2006;37(2):1-128.

43. Reid JA. Anopheline mosquitoes of Malaya and Borneo. Kuala Lumpur: Government of Malaysia; 1968.

44. Sallum MAM, Peyton EL, Harrison BA, Wilkerson RC. Revision of the Leucosphyrus group of Anopheles (Cellia) (Diptera, Culicidae). Rev Bras Entomol. 2005:49:1-152.

45. Shannon CE, Weaver W. The mathematical theory of communication. Urbana: University of Illinois Press; 1963.

46. Phillips A, Simon C. Simple, efficient, and nondestructive DNA extraction protocols for arthropods. Ann Entomol Soc Am. 1995;88:281-3.

47. Singh B, Bobogare A, Cox-Singh J, Snounou G, Abdullah MS, Rahman $H A$. A genus- and species-specific nested polymerase chain reaction malaria detection assay for epidemiologic studies. Am J Trop Med Hyg. 1999;60:687-92.

48. Hawkes F, Manin BO, Ng SH, Torr SJ, Drakeley C, Chua TH, Ferguson HM. Evaluation of electric nets as means to sample mosquito vectors host seeking on humans and primates. Parasit Vectors. 2017;10:338.

49. Rohani A, Chan ST, Abdullah AG, Tanrang H, Lee HL. Species composition of mosquito fauna in Ranau, Sabah, Malaysia. Trop Biomed. 2008;25:232-6.

50. Vythilingam I, Chan ST, Shanmugratnam C, Tanrang H, Chooi KH. The impact of development and malaria control activities on its vectors in the Kinabatangan area of Sabah, East Malaysia. Acta Trop. 2005;96:24-30.

51. Hii JLK, Vun YS. A study of dispersal, survival and adult population estimates of the malaria vector, Anopheles balabacensis Baisas (Diptera: Culicidae) in Sabah, Malaysia. Trop Biomed. 1985;2:121-31.

52. McArthur. The control of Anopheles leucospyrus. Malaria conference for the Western Pacific and Southeast Asia Regions, Taipei, 15-27 November 1954

53. Bryan JE, Shearman PL, Asner GP, Knapp DE, Aoro G, Lokes B. Extreme differences in forest degradation in Borneo: comparing practices in Sarawak, Sabah, and Brunei. PLoS ONE. 2013;8:e69679.

54. Jiram Al, Vythilingam I, NoorAzian YM, Yus of YM, Azahari AH, Fong MY. Entomologic investigation of Plasmodium knowlesi vectors in Kuala Lipis, Pahang, Malaysia. Malar J. 2012;11:213.

55. Rosenberg R, Andre RG, Somchit L. Highly efficient dry season transmission of malaria in Thailand. Trans R Soc Trop Med Hyg. 1990;84:22-8.

56. Dewald JR, Fuller DO, Müller GC, Beier JC. A novel method for mapping village-scale outdoor resting microhabitats of the primary African malaria vector, Anopheles gambiae. Malar J. 2016;15:489.
57. Stark DJ, Fornace KM, Brock PM, Abidin TR, Gilhooly L, Jalius C, et al. Long-tailed macaque response to deforestation in a Plasmodium knowlesi-endemic area. EcoHealth. 2019. https://doi.org/10.1007/s1039 3-019-01403-9.

58. Akter R, Vythilingam I, Khaw LT, Qvist R, Lim YAL, Sitam FT, et al. Simian malaria in wild macaques: first report from Hulu Selangor district, Selangor, Malaysia. Malar J. 2015;14:386

59. Lee K, Divis PCS, Zakaria SK, Matusop A, Julin RA, Conway DJ, et al. Plasmodium knowlesi: reservoir hosts and tracking the emergence in humans and macaques. PLoS Pathog. 2011;7:e1002015.

60. Vythilingam I, NoorAzian YM, Huat TC, Jiram Al, Yusri YM, Azahari AH, et al. Plasmodium knowlesi in humans, macaques and mosquitoes in peninsular Malaysia. Parasit Vectors. 2008;1:26.

61. Grigg MJ, Cox J, William T, Jelip J, Fornace KM, Brock PM, et al. Individuallevel factors associated with the risk of acquiring human Plasmodium knowlesi malaria in Malaysia: a case-control study. Lancet Planet Health. 2017;1:e97-104.

62. Verdonschot PFM, Besse-Lototskaya AA. Flight distance of mosquitoes (Culicidae): a metadata analysis to support the management of barrier zones around rewetted and newly constructed wetlands. Limnologica. 2014;45:69-79.

63. Brant HL, Ewers RM, Vythilingam I, Drakeley C, Benedick S. Vertical stratification of adult mosquitoes (Diptera: Culicidae) within a tropical rainforest in Sabah, Malaysia. Malar J. 2016;15:370.

64. Manin BO, Ferguson HM, Vythilingam I, Fornace K, William T, Torr SJ, et al. Investigating the contribution of peri-domestic transmission to risk of zoonotic malaria infection in humans. PLoS Negl Trop Dis. 2016;10:e0005064.

65. Basseri H, Raeisi A, Khakha MJ, Pakarai A, Abdolghafar H. Seasonal abundance and host-feeding patterns of anopheline vectors in malaria endemic area of Iran. J Parasitol Res. 2010. https://doi. org/10.1155/2010/671291.

66. Freire MG, Schweigmann NJ, Svagelj WS, Loetti MV, Jensen O, Burroni NE. Relationship between environmental conditions and host-seeking activity of Ochlerotatus albifasciatus (Diptera: Culicidae) in an agroecosystem and in an urban area in Chubut, central Patagonia, Argentina. J Nat Hist. 2016:50:1369-80.

67. Stone C, Chitnis N, Gross K. Environmental influences on mosquito foraging and integrated vector management can delay the evolution of behavioral resistance. Evol Appl. 2015. https://doi.org/10.1111/eva.12354.

68. William T, Jelip J, Menon MY, Anderios F, Mohammad R, Mohammad TAAM, et al. Changing epidemiology of malaria in Sabah, Malaysia: increasing incidence of Plasmodium knowlesi. Malar J. 2014;13:390.

69. Nakazawa S, Marchand RP, Quang NT, Culleton R, Manh ND, Maeno Y. Anopheles dirus co-infection with human and monkey malaria parasites in Vietnam. Int J Parasitol. 2009;39:1533-7.

70. Coatney GR, Chin W, Contacos PG, King HK. Plasmodium inui, a quartantype malaria parasite of old world monkeys transmissible to man. J Parasitol. 1966;52:660-3.

71. Imwong M, Madmanee W, Suwannasin K, Kunasol C, Peto TJ, Tripura R, et al. Asymptomatic natural human infections with the simian malaria parasites Plasmodium cynomolgi and Plasmodium knowlesi. J Infect Dis. 2018. https://doi.org/10.1093/infdis/jiy519.

72. Ta TH, Hisam S, Lanza M, Jiram Al, Ismail N, Rubio JM. First case of naturally acquired human infection with Plasmodium cynomolgi. Malar J. 2014;13:68

\section{Publisher's Note}

Springer Nature remains neutral with regard to jurisdictional claims in published maps and institutional affiliations. 